\title{
Hubungan hiperurisemia dengan kardiomegali pada pasien gagal jantung kongestif
}

\author{
${ }^{1}$ Keishi G. D. Masengi \\ ${ }^{2}$ Jeffrey Ongkowijaya \\ ${ }^{2}$ Frans E. Wantania
}

\author{
${ }^{1}$ Kandidat Skripsi Fakultas Kedokteran Universitas Sam Ratulangi Manado \\ ${ }^{2}$ Bagian Ilmu Penyakit Dalam Fakultas Kedokteran Universitas Sam Ratulangi Manado \\ Email: keishimasengi04@gmail.com
}

\begin{abstract}
Hyperuricemia leads to left ventricular hypertrophy that affects the occurrence of congestive heart failure. Increased uric acid level causes increased production of reactive oxygen species (ROS). This ROS stimulates tumor necrosis factor-alpha (TNF- $\alpha$ ) which binds to tumor necrosis factor receptor (TNFR) in the heart, causing a series of reactions of myocyte apoptosis and fibrosis with left ventricular hypertrophy as the final result. This study aimed to determine the relationship between hyperuricemia and cardiomegaly in patients with congestive heart failure. This was an analytical study with a cross sectional design. Samples were 30 patients with congestive heart failure hospitalized in Irina F and Cardio Vascular Brain Center Prof. Dr. R. D. Kandou Hospital in Manado. The result of independent T test stated that there was a significant association between hyperuricemia and cardiomegaly in patients with congestive heart failure with a p value 0,020 and an odds ratio of 3.571.
\end{abstract}

Keywords: hyperuricemia, cardiomegaly, left ventricular hypertrophy, congestive heart failure

\begin{abstract}
Abstrak: Hiperurisemia menyebabkan terjadinya hipertrofi ventrikel kiri sehingga berdampak terjadinya gagal jantung kongestif. Peningkatan kadar asam urat menyebabkan peningkatan produksi reactive oxygen species (ROS). ROS akan menstimulasi tumour necrosis factoralpha (TNF- $\alpha$ ) yangs selanjutnya akan berikatan dengan tumour necrosis factor receptor (TNFR) di jantung sehingga menyebabkan serangkaian reaksi apoptosis miosit dan fibrosis dengan hasil akhir hipertrofi ventrikel kiri. Penelitian ini bertujuan untuk mengetahui hubungan hiperurisemia dengan kardiomegali pada pasien gagal jantung kongestif. Penelitian ini menggunakan metode analitik dengan desain potong lintang. Sampel penelitian ini ialah 30 pasien gagal jantung kongestif di rawat inap Irina F dan Cardio Vascular Brain Center RSUP Prof. Dr. R. D. Kandou Manado. Hasil Uji T Independent menyatakan bahwa ada hubungan bermakna antara hiperurisemia dan kardiomegali pada pasien gagal jantung kongestif $(\mathrm{p}=0,020)$, dengan nilai odds ratio sebesar 3,571.
\end{abstract}

Kata kunci: hiperurisemia, kardiomegali, hipertrofi ventrikel kiri, gagal jantung kongestif

Gagal jantung adalah suatu keadaan patofisiologi dimana jantung gagal mempertahankan sirkulasi adekuat untuk kebutuhan tubuh meskipun tekanan pengisian cukup. Gagal jantung juga adalah sindrom klinis, di tandai oleh sesak napas dan fatik baik saat istirahat atau saat aktivitas yang disebabkan oleh kelainan struktur atau fungsi jantung. Prevalensi gagal jantung berdasarkan yang terdiagnosis dokter atau gejala sebesar $0,3 \%$, dimana prevalensi gagal jantung berdasarkan terdiagnosis dokter tertinggi di Yogyakarta (0,25\%), disusul Jawa Timur (0,19\%), Jawa Tengah $(0,18 \%)$ sedangkan prevalensi gagal jantung di Sulawesi Utara $(0,14 \%))^{1,2}$

Hiperurisemia adalah keadaan dimana 
terjadinya peningkatan kadar asam urat diatas normal. Apabila terjadi kelebihan pembentukan atau penurunan eksresi maka akan terjadi peningkatan konsentrasi asam urat dalam darah. Secara biokimiawi akan terjadi hipersaturasi yaitu, kelarutan asam urat pada serum yang melewati ambang batas. Peningkatan kadar asam urat dalam darah hingga melebihi $6,8 \mathrm{mg} / \mathrm{dL}$ pada pria dan 6,0 $\mathrm{mg} / \mathrm{dL}$ pada wanita dapat dikatakan kondisi hiperurisemia. Prevalensi hiperurisemia di Minahasa berdasarkan penelitian sebelumnya diperoleh angka kejadian hiperurisemia $34,30 \%$ pada pria dan $23,31 \%$ pada wanita dengan rerata kadar asam urat pada pria $6,60 \mathrm{mg} / \mathrm{dl}$ dan wanita 5,1 mg/dl.,4 Pada hasil penelitian sebelumnya terdapat hubungan yang bermakna antara hiperurisemia dengan kejadian hipertrofi ventrikel kiri pada mahasiswa pria peserta KKM di FK Unsrat Manado. ${ }^{5}$

Teori Framingham Heart Study juga menyatakan bahwa peningkatan kadar asam urat bukan merupakan faktor risiko utama kejadian gagal jantung namun merupakan salah satu faktor pendukung terjadinya gagal jantung. Penjelasannya ialah peningkatan kadar asam urat berkontribusi terhadap munculnya gangguan produksi nitrat oksida dan disfungsi endotel, peningkatan kekakuan pembuluh darah, aktivasi renin-angiotensin aldosteron yang tidak sesuai, peningkatan stres oksidatif, dan respon inflamasi. Semua kelainan ini menyebabkan gangguan fungsi dari pembuluh darah dan menyebabkan gagal jantung. ${ }^{6}$ Hipertrofi ventrikel kiri sebagai faktor resiko independen, berperan penting dalam terjadinya gagal jantung. Hipertrofi ventrikel kiri sebagai kompensasi terhadap peningkatan tekanan darah sistemik, yang pada akhirnya justru meningkatkan kerja jantung dan menyebabkan gagal jantung. ${ }^{7}$

Penelitian ini bertujuan untuk mengetahui hubungan hiperurisemia dengan kardiomegali pada pasien gagal jantung kongestif di RSUP Prof. Dr. R.D Kandou Manado.

\section{METODE PENELITIAN}

Penelitian ini bersifat analitik dengan menggunakan desain potong lintang. Penelitian dilakukan di rawat inap Irina $\mathrm{F}$ dan rawat inap Cardio Vascular Brain Center RSUP Prof. Dr. R.D. Kandou, Manado pada bulan Oktober - Desember 2015. Populasi penelitian ini ialah pasien gagal jantung kongestif yang di rawat inap Irina $\mathrm{F}$ dan rawat inap Cardio Vascular Brain Center RSUP Prof. Dr. R.D. Kandou, Manado.

Pengabilan sampel dilakukan secara non-probability sampling dengan teknik consecutive sampling. Jumlah sampel yang diperoleh sebanyak 30 orang.

\section{HASIL PENELITIAN}

Dari 30 sampel penelitian, 15 orang dengan hiperurisemia dan kardiomegali, 7 orang dengan hiperurisemia dan tidak kardiomegali, 3 orang dengan tidak hiperurisemia tetapi dengan kardiomegali, 5 orang dengan tidak hiperurisemia dan tidak kardiomegali.

Karakteristik sampel penelitian meliputi umur, jenis kelamin, pekerjaan, kadar asam urat, tekanan darah sistolik (TDS), dan tekanan darah diastolik (TDD).

Tabel 1 menunjukkan bahwa sampel berusia 51-70 tahun berjumlah lebih banyak yaitu sebanyak 23 orang $(76,7 \%)$, sedangkan sampel berusia 21-50 tahun sebanyak 6 orang (20\%), diikuti dengan sampel berusia di atas 70 tahun berjumlah 1 orang (3,3\%).

Tabel 1. Distribusi Karakteristik Sampel menurut Umur

\begin{tabular}{ccc}
\hline Umur & $\mathrm{n}$ & $\%$ \\
\hline $21-50$ & 6 & 20 \\
$51-70$ & 23 & 76,7 \\
$>70$ & 1 & 3,3 \\
Total & 30 & 100 \\
\hline
\end{tabular}

Tabel 2 menunjukkan bahwa sampel terbanyak ialah laki-laki yaitu 20 orang (66,7\%) sedangkan sampel perempuan berjumlah 10 orang (33,3\%). 
Tabel 2. Distribusi Karakteristik Sampel menurut Jenis Kelamin

\begin{tabular}{ccc}
\hline Jenis Kelamin & $\mathrm{n}$ & $\%$ \\
\hline Laki-laki & 20 & 66,7 \\
Perempuan & 10 & 33,3 \\
Total & 30 & 100 \\
\hline
\end{tabular}

Tabel 3 menunjukkan bahwa sampel terbanyak dari kalangan pensiunan sebanyak 10 orang $(33,4 \%)$ dan sampel yang paling sedikit dari kalangan belum bekerja dan petani yaitu 1 orang (3,3\%). Sisanya ialah sampel dengan pekerjaan sebagai swasta (30\%), Ibu Rumah Tangga (23,3\%), dan pekerjaan PNS (6,7\%).

Tabel 3. Distribusi Karakteristik Sampel Pekerjaan

\begin{tabular}{ccc}
\hline Pekerjaan & $\mathrm{n}$ & $\%$ \\
\hline PNS & 2 & 6,7 \\
Swasta & 9 & 30 \\
IRT & 7 & 23,3 \\
Petani & 1 & 3,3 \\
Pensiunan & 10 & 33,4 \\
Tidak ada & 1 & 3,3 \\
Total & 30 & 100 \\
\hline
\end{tabular}

Tabel 4 menunjukkan bahwa sampel dengan kadar asam urat $>7 \mathrm{mg} / \mathrm{dL}$ sebanyak 21 orang (70\%), sedangkan sampel dengan kadar asam urat 3-7mg/dL sebanyak 9 orang (30\%).

Tabel 4. Distribusi Karakteristik sampel menurut Kadar Asam Urat

\begin{tabular}{ccc}
\hline Kadar & $\mathrm{n}$ & $\%$ \\
Asam Urat & & \\
\hline$>7 \mathrm{mg} / \mathrm{dL}$ & 21 & 70 \\
$3-7 \mathrm{mg} / \mathrm{dL}$ & 9 & 30 \\
Total & 30 & 100 \\
\hline
\end{tabular}

Tabel 5 menunjukkan bahwa mayoritas ialah sampel dengan TDS $<120 \mathrm{mmHg}$ sebanyak 16 orang (53,4\%), sedangkan minoritas ialah sampel dengan TDS $>160$ mmHg sebanyak 3 orang (10\%).

Tabel 6 menunjukkan bahwa mayoritas ialah sampel dengan TDD $<80 \mathrm{mmHg}$ (63,3\%), sedangkan minoritas sampel dengan TDD 90-99 mmHg (6,7\%) dan $>100 \mathrm{mmHg}(6,7 \%)$.

Tabel 5. Distribusi Karakteristik sampel menurut TDS

\begin{tabular}{ccc}
\hline TDS & $\mathrm{n}$ & $\%$ \\
$<120 \mathrm{mmHg}$ & 16 & 53,4 \\
$120-139 \mathrm{mmHg}$ & 7 & 23,3 \\
$140-159 \mathrm{mmHg}$ & 4 & 13,3 \\
$>160 \mathrm{mmHg}$ & 3 & 10 \\
Total & 30 & 100 \\
\hline
\end{tabular}

Tabel 6. Distribusi Karakteristik sampel menurut TDD

\begin{tabular}{ccc}
\hline TDD & $\mathrm{n}$ & $\%$ \\
\hline$<80 \mathrm{mmHg}$ & 19 & 63,3 \\
$80-89 \mathrm{mmHg}$ & 7 & 23,3 \\
$90-99 \mathrm{mmHg}$ & 2 & 6,7 \\
$>100 \mathrm{mmHg}$ & 2 & 6,7 \\
Total & 30 & 100 \\
\hline
\end{tabular}

Berdasarkan Tabel 7, hasil analisis Odds ratio antara hiperurisemia dengan kardiomegali 3,571 yang artinya pasien dengan hiperurisemia berisiko kejadian kardiomegali sebesar 3,571 kali lipat dibanding dengan pasien tanpa hiperurisemia dengan confidence interval $95 \% 0,66-19,34$.

Tabel 7. Estimasi odds ratio dan confidence interval antara hiperurisemia dengan kejadian hipertrofi ventrikel kiri

\begin{tabular}{cc|cc}
\hline \multirow{2}{*}{} & \multirow{2}{*}{$\begin{array}{c}\text { 95\% Confidence } \\
\text { Interval }\end{array}$} \\
\cline { 3 - 4 } & Nilai & Lower & Upper \\
\hline Odds & & \multicolumn{2}{|}{} \\
Ratio & 3,571 & \multirow{2}{*}{, 659} & 19,341 \\
Total & 30 & \multicolumn{2}{c}{} \\
\hline
\end{tabular}

Berdasarkan Tabel 8, dari kolom uji T 2-sisi menunjukan nilai $\mathrm{P}=0,020$. Karena nilai P lebih kecil dari $\alpha=0,05$ berarti Ho ditolak, sehingga dapat disimpulkan bahwa ada pengaruh antara hiperurisemia dan hipertrofi ventrikel kiri.

Uji normalitas dilakukan terhadap kedua kelompok diatas untuk apabila terdistribusi normal. Dari uji KolmogorovSmirnov didapatkan nilai LVH positif $\mathrm{P}=$ 
0,200 dan nilai $\mathrm{LVH}$ negatif $\mathrm{P}=0,191$. Karena nilai $\mathrm{P}>0,05$ maka kedua kelompok terdistribusi normal. Oleh karena itu data yang dianalisis menggunakan Uji $\mathrm{T}$ tidak berpasangan.

Tabel 8. Uji Normalitas Data

\begin{tabular}{c|c|c|c|c}
\hline & \multirow{2}{*}{} & \multicolumn{4}{|c}{ Kolmogorov-Smirnov } \\
\cline { 3 - 5 } & LVH & Statistic & df & Sig. \\
\hline Kadar & & & & \\
Asam & Positif &, 075 & 18 &, $200^{*}$ \\
\cline { 2 - 5 } Urat & Negatif &, 202 & 12 &, 191 \\
\hline
\end{tabular}

Box-plot pada Gambar 1 memperlihatkan bahwa distribusi sampel pasien dengan LVH positif lebih tinggi dibanding dengan LVH negatif.

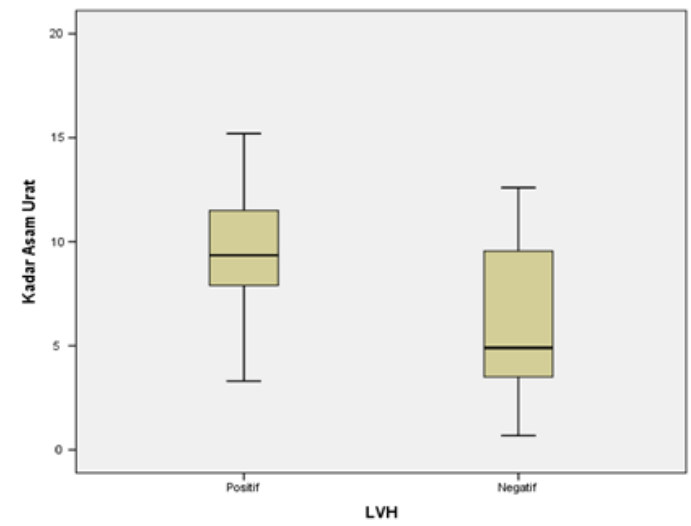

Gambar 1. Box-plot perbandingan distribusi $\mathrm{LVH}$ positif dan $\mathrm{LVH}$ negatif terhadap kadar asam urat

Tabel 9. Uji T Tidak Berpasangan

\begin{tabular}{cccc}
\hline $\begin{array}{c}\text { Levene's } \\
\text { Test for } \\
\text { Equality of } \\
\text { Variances }\end{array}$ & \multicolumn{3}{c}{ t-test for Equality of } \\
Means
\end{tabular}

\section{BAHASAN}

Penelitian ini bertujuan untuk mengetahui hubungan hiperurisemia dengan kardiomegali pada pasien gagal jantung kongestif di RSUP Prof. Dr. R. D Kandou Manado. Pada penelitian ini di gunakan kriteria hiperurisemia menurut Council For International Organization of Medical Sciences (CIOMS) yaitu $>7 \mathrm{mg} / \mathrm{dL}$ untuk pria dan $>6 \mathrm{mg} / \mathrm{dL}$ untuk wanita, dan ekokardiografi untuk mendiagnostik LVH.

Hasil uji statistik pada 30 sampel gagal jantung kongestif (20 pria dan 10 wanita) menunjukkan bahwa ada hubungan bermakna antara kadar asam urat dengan LVH pada pasien gagal jantung kongestif. Didapatkan nilai $(\mathrm{p}=0,020)$ pada analisa Uji $\mathrm{T}$ independen 2 sisi yang menyatakan ada hubungan bermakna antara kadar asam urat dan LVH. Pada penelitian ini didapatkan nilai estimasi odds ratio 3,571 kali lipat yang artinya pasien dengan hiperurisemia mempunyai resiko 3,571 kali lipat untuk mengalami LVH.

Faktor lain yang diduga dapat memengaruhi LVH ialah hipertensi. Hal ini terjadi karena jantung mengalami hipertrofi dalam usaha kompensasi akibat beban tekanan (pressure over load) atau beban volume (volume overload) yang mengakibatkan peningkatan tegangan dinding otot jantung. ${ }^{7}$ Hipertrofi ventrikel kiri dimulai dengan peningkatan kontraktilitas miokard yang dipengaruhi oleh sistem saraf adrenergik sebagai respon neurohumoral, kemudian diikuti dengan peningkatan aliran darah balik vena karena vasokontriksi pembuluh darah perifer dan retensi cairan oleh ginjal. ${ }^{8}$ Bertambahnya volume darah dalam vaskuler akan meningkatkan beban kerja jantung, kontraksi otot jantung akan menurun karena suplai aliran darah yang menurun dari aliran koroner akibat arteriosklerosis dan berkurangnya cadangan aliran pembuluh darah koroner. Dengan peningkatan tahanan perifer dan beban sistolik ventrikel kiri, jantung mengalami hipertrofi karena aktifasi simpatis untuk meningkatkan kontraksi miokard. ${ }^{7,8}$ Namun pada penelitian ini faktor hipertensi tidak dikeluarkan saat pengambilan sampel.

Hasil penelitian ini sesuai dengan penelitian Rinaldi ${ }^{9}$ dengan uji korelasi didapatkan $p=0,029$ yang menyatakan terdapat hubungan signifikan antara hiperurisemia dengan kejadian hipertrofi 
ventrikel kiri. Dari kesimpulan peneliti di atas dikatakan bahwa kombinasi hiperurisemia dengan hipertrofi ventrikel kiri merupakan prediktor kuat penyebab penyakit jantung dan pembuluh darah. ${ }^{9}$ Dalam case-control the Framingham heart study mengatakan bahwa dalam kasus yang parah hipertrofi ventrikel kiri kronis yang berhubungan dengan disfungsi diastolik dan fraksi ejeksi diawetkan, pasien laki-laki dan perempuan mungkin mengalami episodik parah gagal jantung kongestif dan rawat inap. ${ }^{10}$

Penelitian yang dilakukan Fujita $^{11}$ melaporkan bahwa kejadian hipertrofi ventrikel kiri yang dipengaruhi oleh asam urat bergantung pada kadar paratiroid hormon. Dalam uji multivariat regresi logistik yang dilakukan Fujita didapatkan odds ratio 2,79 kali lipat berpengaruh dan terdapat hubungan bermakna dengan nilai $\mathrm{P}=0,002$ sehingga disimpulkan bahwa hubungan kadar asam urat dengan kejadian hipertrofi ventrikel kiri bergantung juga dengan tingkat paratiroid hormon. ${ }^{11}$

Mekanisme hiperurisemia menyebabkan hipertrofi ventrikel kiri yaitu kondisi hiperurisemia dapat meningkatkan aktivitas enzim xantin oksidase. Enzim xantin oksidase membentuk superoksida sebagai akibat langsung dari aktivitasnya. Peningkatan jumlah oksidan menyebabkan stres oksidatif yang semakin menurunkan produksi nitrik oksida (NO) dan menyebabkan disfungsi endotel. Efek enzimatik xantin oksidase ialah produksi reactive oxigen species (ROS) dan asam urat. Peningkatan ROS ini akan memicu aktivasi PKC yang berakibat timbulnya peningkatan protein proinflamasi dan proaterogenik. $^{12}$

ROS merangsang proses inflamasi dengan mengeluarkan sitokin proinflamatorik dan akan menstimulasi inflamasi secara terus menerus yang akan menyebabkan inflamasi. ${ }^{13}$ ROS menyebabkan pelepasan sitokin seperti interleukin-6 (IL-6) dan tumor necrosis factor-alpha (TNF- $\alpha$ ), sehingga meningkatkan jumlah produksi leukosit polimorfonuklear. ${ }^{14}$ TNF$\alpha$ adalah sitokin proinflamasi yang menghasilkan disfungsi ventrikel kiri, kardiomiopati, dan edema paru ketika diekspresikan dalam subyek manusia. ${ }^{15,16}$ Tingkat TNF-a yang tinggi menyebabkan sitokin tersebut akan berikatan dengan reseptornya di miokard. Terdapat reseptor TNF tipe 1 (TNFR1) dan tipe 2 (TNFR2) di kardiomiosit manusia dewasa. Telah teridentifikasi bahwa di kardiomiosit kontraktil terisolasi, efek inotropik negatif dimediasi oleh TNFR1. ${ }^{17}$ Bukti yang berkembang berimplikasi TNF- $\alpha$ dalam patogenesis gagal jantung. Terdapat laporan studi yang menyatakan bahwa tikus transgenik yang terekspresi kronis TNF-a berlanjut menjadi hipertrofi jantung, fibrosis, dan kardiomiopati dilatasi. ${ }^{18}$

Penelitian ini juga sesuai dengan penelitian yang dilakukan oleh Nangoy ${ }^{19}$ mengenai pengaruh kadar asam urat terhadap pembesaran massa ventrikel kiri. Pada uji korelasi Pearson didapatkan kadar asam urat dengan LVMI memiliki hubungan yang signifikan dengan nilai $\mathrm{P}=0,005$, sehingga disimpulkan bahwa kadar asam urat berperan terhadap peningkatan massa otot ventrikel kiri. ${ }^{19}$

\section{SIMPULAN}

Berdasarkan hasil penelitian yang telah dilakukan dapat disimpulkan terdapat hubungan bermakna antara hiperurisemia dengan kardiomegali pada pasien gagal jantung kongestif.

\section{SARAN}

1. Sebaiknya dilakukan penelitian lain dengan memperhitungkan faktor perancu lain yang belum dapat dikendalikan pada penelitian ini.

2. Pasien gagal jantung kongestif yang memiliki kadar asam urat tinggi sebaiknya diberikan pengobatan secepatnya untuk mencegah terjadinya komplikasi parah.

\section{DAFTAR PUSTAKA}

1. Kasper DL, Braunwald E, Fauchi AS Braunwald E. Heart Failure and Cor Pulmonal. In: eds. Harisson's principles of internal medicine 16 ed, 
2003 : 1367-1377.

2. Kementrian Kesehatan RI. Riset Kesehatan Dasar (RISKESDAS). 2013 [dikutip 201510 05]. Available from: http://www.litbang.depkes.go.id/sites/ download/rkd2013/Laporan_Riskesda s2013.PDF.

3. Dipiro JT, Robert LT, Gary CY, Gary RM, Barbara GW, Michael L (Editors). Pharmacotherapy a Pathophysiologic Approach (8th ed). New York: The Mc Graw-Hill Companies, 2011,

4. Rotty LWA, Karema AMC. Gambaran asam urat pada suku minahasa usia dewasa muda (laporan Penelitian). Manado: Universitas Sam Ratulangi, 1999.

5. Wowor R, Kandou G, Umboh G. Faktorfaktor yang mempengaruhi pembesaran jantung kiri (LVH) pada mahasiswa pria peserta Kepanitraan Klinik Madya Fakultas Kedokteran Sam Ratulangi Manado. Program Pasca Sarjana. Universitas Sam Ratulangi, 2015.

6. Culleton BF, Larson MG, Kannel WB, Levy D. Serum uric acid and risk for cardiovascular disease and death: the Framingham heart study. Ann Intern Med. 1999;131:7-13.

7. Horrower A, Mc Farlane G. Left ventricular hypertrophy in hypertension. Am J Med. 1998;(S)1B :89-91.

8. Mayet J, Shahi M, Mcgrah K, Poulter NR, Sever PS, et al. Left Ventricular hypertrophy and QT dispersion in Hypertension. Hypertension. 1996: 791-6.

9. Rinaldi ER, Bentivenga C, Cosentino E, Corvaglia S, Rosticci $M$, et al. Correlation between Serum Uric Acid and Left Ventricular Mass in Essential Hypertension. In: ARD the Eular Journal, 2015.

10.Vasan RS, Larson MG, Benjamin EJ, et al. Congestive heart failure in subjects with normal versus reduced left ventricular ejection fraction: prevalence and mortality in a population-based cohort. J Am Coll
Cardiol. 1999;33:1948-55.

11.Fujita S-i, Okamoto Y, Shibata K, Morita H, Ito T, Sohmiya K, et al. Serum Uric Acid is Associated with Left Ventricular Hypertrophy Independent of Serum Parathyroid Hormone in Male Cardiac Patients. PLoS ONE 8(12):e82735. doi:10.1371/journal.pone.0082735 2013

12.Johnson RJ, Kang DH, Feig D, Kivlighn S, Kannelis J, Watanabe S, et al. Is there a pathogenetic role for uric acid in hypertension and cardiovascular and renal disease. Hypertension. 2003 41:1183-90.

13.Malik M. Bathcarov VN. Measurement, interpretation and clinical potential of QT dispersion. J. Am Coll Cardiol. 2000.

14. Chapple ILC. Role of free radicals and antioxidants in the pathogenesis of inflammatory periodontal disease. Clinical Molecular Pathology. 1996; 49:247-55.

15.Suffredini AF, Fromm RE, Parker MM, Brenner M, Kovacs JA, Wesley RA, et al. The cardiovascular response of normal humans to the administration of endotoxin. $\mathrm{N}$ Engl $\mathrm{J}$ Med. 1989;321:280-7.

16.Hegewisch S, Weh HJ, Hossfeld DK. TNF-inducedcardiomiopathy. Lancet $1990 ; 2: 294-5$

17.Torre-Amione G, Kapadia S, Lee J, Bies RD, Lebovitz R, Mann DL. Expression and functional significance of tumor necrosis factor receptors in human myocardium. Circulation. 1995;92: 1487-93.

18.Herrera GE, Cubillos GA, Stetson SJ, Cano NR, Herrera FF, Durand JB et al. Factor de necrosis tumoral- $\alpha$ : un mediador en la patogénesis de la insuficiencia cardiaca. Arch Inst Cardiol Mex. 1999;69:462-8.

19.Nangoy J, Wantania FE. Hubungan antara kadar asam urat dengan massa otot ventrikel kiri pada pasien dengan hipertensi. Makalah Bebas Pit Pernefri, 2015. 